\title{
Incorrigible While Incarcerated: Critically Analyzing Mainstream Canadian News Depictions of Ashley Smith
}

\section{Jessi Ring \\ Carleton University}

Ashley Smith, who is typically presented in the media as mentally ill, was nineteen years old when she died from self-strangulation in an Ontario women's prison on October $19^{\text {th }}, 2007$. In this paper, I explore how Ashley Smith's actions and death were portrayed in four mainstream Canadian newspapers (Globe and Mail, Telegraph-Journal, Toronto Star and National Post). My aims in this paper are to critically analyze depictions of mental illness presented by these news articles and connect these portrayals to labeling theories. Two variables - the timing of the news coverage and newspaper political affiliation-emerged as being influential in how newspapers depicted Ashley Smith as mentally ill, through their use of generic and/or negative terminology and vulnerability stereotypes. I also discuss 'alternative' stories of Ashley Smith and examine their potential to challenge typical conceptualizations of mental illness, gender and carceral environments.

Keywords: Ashley Smith; mental illness; labeling theory; gender; media

Ashley Smith, généralement représentée dans les médias comme une personne souffrant de maladie mentale, avant dix-neuf ans quand elle est morte d'auto strangulation dans une prison pour femmes de l'Ontario le 19 octobre 2007. Dans cette étude, j'aborderai comme les gestes et la mort de Ashley Smith ont été décrits dans quatre grands journaux publics canadiens (Globe and Mail, Telegraph-Journal, Toronto Star et le National Post). Dans cet article, mon objectif est d'analyser de manière critique la description de la maladie mentale dans les articles, et de relier ces descriptions à des théories sur les stéréotypes. Deux variables, à savoir le moment de la publication de la nouvelle et l'appartenance politique du journal, se sont révélés des facteurs d'influence sur la description faite par les journaux de la maladie mentale de Ashley Smith, tel que l'illustrent l'utilisation de terminologie générique ou négative et de stéréotypes de vulnérabilité. J'aborderai aussi des narratifs «alternatifs » de l'histoire de Ashley Smith, et étudier comment ils pourraient remettre en question les concepts répandus sur la maladie mental, le genre et les milieux carcéraux.

Mots clés: Ashley Smith; maladies mentale; théorie de l'étiquetage; sexe; média

\section{Introduction}

October 19th, 2012 marked the fifth anniversary of Ashley Smith's death. At the time of her passing, Ashley was a prisoner at Grand Valley Institution for Women - a multi-level federal penitentiary located in Kitchener, Ontario (Correctional Service of Canada, 2012). She died while under 24-hour video surveillance 'suicide watch'. Seven trained correctional officers observed and failed to intervene as she strangled herself with a cloth ligature. She was nineteen years old.

Although deaths in custody are not unique, media coverage of Ashley Smith's treatment and untimely death in corrections has helped publicize serious institutional problems in Canadian youth and women's correctional facilities. The media interest surrounding the Ashley Smith case presents an opportunity to examine how one high-profile death in custody was covered. In this 
paper, I investigate how Ashley Smith has been portrayed in four mainstream Canadian newspapers (Globe and Mail, Toronto Star, Telegraph-Journal and National Post). More specifically, I explore in what ways the news coverage labels Ashley Smith as mentally ill and/or defines her behaviour and death following a rubric of mental illness stereotypes. According to labeling theories, mental illness labels are socially constructed and are rooted in stereotypical notions of race and gender. Under this theoretical framework, media depictions of mental illness perpetuate negative stereotypes of 'the mentally ill', which impact public perceptions of mental illness. In this analysis, depictions of mental illness changed depending on the timing of the news coverage, the newspaper's political affiliation, and the location of newspapers. The findings of this paper contribute to existing research that uses modified labeling theories by exposing the complexity of mental health labeling in Canadian news media.

\section{A Critical Appraisal of Labeling Theory Trends}

Ashley Smith is typically described as someone who was mentally ill. In this paper, I consider the significance of labeling Ashley Smith as mentally ill by using labeling theories as a theoretical framework. Sociological theorizing on the significance of mental health labels began in the 1950s, and has since been used to critique mental health discourses that rely on traditional medical models. Many researchers use these theoretical frameworks, labeling theories to analyze the stigmatic impacts of mental illness stereotyping in mass media sources, to reject the argument that mental illness labels are applied objectively.

T.J. Scheff's $(1966,1974)$ work serves as a foundation for the discourse relating to labeling theory and the construction of mental health. Scheff explains that labeling theory is a tool that can create another narrative about mental illness. His intention is not to supplant existing research, nor deny the material realities of individuals living with mental illness. He uses labeling theory to provide a theoretical model that is based outside the medical model (Scheff, 1974). The medical model of mental health is rooted in the 'psy' sciences - psychiatry and psychology. The major assumption of this perspective is that mental illness causality is rooted in underlying biological 'abnormalities' (McLeod, 2008). This means that symptoms of mental illness are understood as "outward signs of the inner physical disorder" (McLeod, 2008, n.p.), which are "grouped together and classified into a 'syndrome"" (emphasis in original; McLeod, 2008, n.p.). Ultimately, the medical model assumes that "the true cause [of mental illness] can eventually be discovered and appropriate physical treatment administered" (McLeod, 2008, n.p.).

On the other hand, Scheff's non-medical model postulates that being labeled as mentally ill causes one to become 'mentally ill'; thus, individuals who are labeled mentally ill internalize stereotypical depictions of mental illness and recreate their self-concept as one who is mentally ill (Merton, 1948; Scheff, 1966). Scheff maintains that "traditional stereotypes of mental disorder are solidly entrenched in the population because they are learned in early childhood and are continuously reaffirmed in the mass media and everyday conversation" (1966, p. 84-85). Internalization of these public stigmas results in mental illness labels and diagnoses becoming a self-fulfilling prophecy: mentally ill individuals perform their illness in accordance with that particular illness's role expectations (Scheff, 1966). For example, an individual diagnosed with depression will embody and perform stereotypical understandings of what depression looks like based on depictions presented in mass media and other social institutions - attributes such as, being socially withdrawn, bedridden, apathetic, and having degraded personal hygiene. The medical model would maintain that these behaviours are symptomatic of depression and are rooted in 
physiological deficiencies; however, labeling theory contends that in being labeled or diagnosed with depression - as opposed to 'sadness' - the individual identifies as being someone who is 'depressed' and performs accordingly.

Scheff's original work on labeling theory and mental health invoked harsh criticisms from other sociological theorists. As a result, Link and colleagues (1989) modified Scheff's theory (Pasman, 2011). The fundamental difference between these two theoretical approaches to mental illness is that the modified labeling theory removed indications relating to causation, such that it was no longer argued that labeling or diagnosis causes mental illness, but that it is related to how an individual's behaviours are understood by themselves and others. This difference means that modified labeling theorists are more interested in exploring why specific labels matter, as opposed to explaining how labels create mental illness (O'Connor, 2006). According to modified labeling theory, "diagnosis has a negative influence on self-concept through stigma and stigma expectations" (emphasis added; Pasman, 2011, p. 124).

Mental illness labels create a dichotomous 'us' ('normal' people) versus 'them' ('mentally ill' people) relationship. The 'mentally ill' out-group is perceived as homogenous and is socially defined as a whole by negative stereotypes (e.g., unpredictability, dangerousness, laziness) that lead to discrimination and social exclusion (Pasman, 2011). These visions of the mentally healthy/ill dichotomy and the social exclusion of mentally ill individuals are supported by research conducted by Pat Caplan (1995). According to Caplan, images of mental illness "suggest that 'they' are not as competent, human, or safe to be around as the rest of "us"" (1995, p. 11). Furthermore, someone who is labeled as mentally ill is "someone who is out of control, out of touch with 'reality', incapable of forming a good relationship, untrustworthy, quite possibly dangerous, and probably not worth one's attention, time or energy" (Caplan, 1995, p. 11). Mental illness is labeled as a social 'problem' that requires professional intervention and treatment.

Sociological research has also challenged the notion that mental illnesses are universal across cultures, disrupting the medical model's assumption that mental illness is organic in nature (Morgan et al, 2008). Caplan (1995) maintains that mental health professionals rarely agree upon mental illness labels, diagnoses, or treatment plans. This means that people should be critical of mental illness labels. In particular, Caplan argues that we must ask "for what purpose they are making that judgment" (emphasis in original; 1995, p. 44), and if the intention is to 'help' someone, is there any evidence that "applying an abnormality label will actually further this intention" (1995, p. 44)? Blum (2011) maintains that people must be critical of the omnipresence of medical nomenclature in everyday life. He refers to this overreach of the medical profession as medicalization: "a means (almost as a tool or technology) for expanding the jurisdiction of medicine by redefining social issues as problems that require medical intervention and regulation or, at least, official consultation and use of medical expertise" (Blum, 2011, p. 170). It is through medicalization that medical practices serve as "biomedical weapons in the colonization of everyday life" (Blum, 2011, p.170), acting as tools for social control and deviance regulation. This omnipresence of medicalization in social institutions is linked to the institutionalization and marginalization of non-hegemonic identities.

'Health' and 'illness' are not natural categorizations. Instead, these labels entail "meaningful practices which raise questions of evaluation and appraisal that are [considered] fundamental [to the medical model]" (Blum, 2011, p. 118). Doucet, Letourneau and Stoppard (2010) maintain that researchers studying mental illness must move beyond medical model approaches by utilizing "a framework that facilitates the examination of how social, political, economic, ethnic, gender, and cultural factors interact to influence mental health and illness 
experiences" (p. 305). In the next section, I engage with these critical discourses further as I explore how gender and race connect with mental illness labeling theories.

\section{Women in the 'Mental Health' Turn: Labeling Theories and Gender}

Betty Friedan began problematizing the notion of medicalizing gender role incongruence in her book, The Feminine Mystique (1963). Coining the term "the problem that has no name" (1963, p. 57), Friedan explores the widespread dissatisfaction and unhappiness (white, middle class) American suburban housewives felt post-World War II. Friedan (1963) openly critiques the medical treatment of the pressures and dissatisfaction that coincide with American femininity and argues that women should explore finding personal fulfillment outside of traditional gender roles.

Launching from this work, Phyllis Chesler (1972) explores the institutionalization of 'mad' women. She contends that stigmatic labels associated with women's mental health serve to reproduce patriarchal and class hierarchies in Canada and other 'Western' countries. Women are stereotypically labeled as 'help-seekers', and there is a wider social acceptance of behaviour displaying 'emotional distress' in women. However, there is a fine line between acceptable femininity and unacceptable femininity. It is acceptable for women to be (somewhat) needy, dependent, weak and helpless, though Chesler maintains that:

...such female behaviour is judged as annoying, inconvenient, stubborn, childish and tyrannical. Beyond a certain point, such behaviour is 'managed' rather than rewarded: it is treated with disbelief and pity, emotional distance, physical brutality, economic and sexual deprivation, drugs, shock therapy, and long-term confinement (1972, p. 39).

As such, women who over-perform acceptable feminine behaviours are considered pitiful, childlike, and immature due to the misogynist and patriarchal undervaluation of femininity. Characteristics that define notions of femininity that can lead to punishment for over-performance include submissiveness, nurturance, sensitivity, and emotional expressiveness (Rosenfield, 2012). Rejecting femininity or over-selling femininity can each result in punitive responses.

Rigid boundaries of acceptable feminine behaviours result in more women transgressing into 'unacceptable' or 'ill' behaviour-behaviour that would be totally acceptable and 'normal' if performed by a man (Chesler, 1972). Sarah Rosenfield (1982) analyzed the influence of sex roles in societal reactions to mental illness by analyzing a random sample of 666 admissions to a New York psychiatric emergency room. She found that sex role expectations influence practitioners' decisions for hospitalization. In particular, men tended to be hospitalized for presenting more 'feminine' types of disorders (e.g., depression) and women tended to be hospitalized for presenting more 'masculine' types of disorders (e.g., drug addiction and alcoholism) (Rosenfield, 1982). Rosenfield (1982) concludes that "the same level or form of behaviour in males and females seems more visible or striking if it contradicts sex role expectations and this appears to the observer as a more problematic form of the behaviour" (p. 23).

Biological sex does not naturally predispose males and females to specific mental illnesses; rather, deviant or 'ill' behaviours are read as such by practitioners through the lens of gender performativity and societal expectations. This research consistently shows that women are susceptible to being labeled mentally ill when they fail to conform to rigid notions of femininity (Rogers \& Pilgrim, 2010). Rosenfield's findings indicate that both men and women can be punitively labeled 'mentally ill' for transgressing gender expectations. However, a patriarchal 
society privileges masculinity, which results in milder policing of men, as they are granted more flexibility in acceptable forms of performance.

Emerging from both Friedan and Chelser's critiques, there is a large body of contemporary work that explores the relationship between gender and mental illness from a labeling theory perspective. Though this work does not explicitly use labeling theory, it relies upon similar theoretical assumptions as those found in labeling theory. First, it is critical of medical definitions that are historically rooted in biological determinism and challenges the 'objectivity' of mental illness labels or diagnoses. Second, it supports the notion found in labeling theory that mental illness labeling is a tool used by the powerful to maintain social oppression and exclusion of the marginal.

Expanding upon the original conceptualizations of femininity, contemporary feminist researchers acknowledge that concepts of femininity intersect with race. For example, Black femininity is constructed as more flexible and interchangeable than white femininity. Black girls are socialized to embrace different aspects of femininity, including inner-strength and selfsufficiency (Rosenfield, 2012). Because of racism, Black women are excluded from rigid notions of white femininity, which means that they are less susceptible to 'traditional' mental illness stigmas (Rosenfield, 2012). However, this does not mean that black women and men do not experience psychological stressors triggered by structural oppressions, such as racism. Black individuals displaying 'ill' behaviours or stressors are less likely to be medically diagnosed as 'mentally ill'. Instead, Black bodies are more likely to be criminalized, labeled as 'violent' or 'criminal' and experience higher rates of incarceration (Jiwani, 2002; Silliman \& Bhattacharjee, 2002; Davis, 2007).

The same could be argued for Aboriginal women: as opposed to being labeled as 'ill', Aboriginal women are more often associated with notions of risk and dangerousness. Like Black women, this means that Aboriginal women who do not conform to colonial expectations of the 'good Aboriginal' (submissive to and accepting of colonial power) are more likely to be criminalized than medicalized. This means that, once again, being less susceptible to mental illness labels does not mean that Aboriginal women do not encounter oppression. This is especially true for incarcerated Aboriginal women, where being labeled 'high risk' means one is not eligible for reintegration activities such as work release programs or temporary passes (Shaw and HannahMoffat, 2000), options which may be available for medication-compliant mentally ill prisoners. 'High risk' classifications are designated to $44 \%$ of federally sentenced Aboriginal women (Pollack, 2008). One of the implications of this over-classification of Aboriginal women is that maximum security classifications prevents access to cultural-specific programming like the Okimaw Ohci Healing Lodge, which only accepts minimum and medium security women (Pollack, 2008). Therefore, $44 \%$ of Aboriginal women serving a federal sentence are automatically excluded from culturally specific programs until they can 'lower' their risk through the acceptance of normalizing (or colonizing) therapeutic programs, which maintain white cultural ideals of 'normalcy' - an ideal that is itself a racialized phenomenon. 'Normalcy' assumes that there exists an ideal type of person. Moral assessments of who can be understood as 'normal' are based on white, heteronormative, middle-class values, lifestyles and experiences. This means that racialized, queer and poor individuals are often cast as 'abnormal', even when they are not labeled as 'mentally ill'. Therefore, avoiding the stigma of one label (mentally ill) does not guarantee freedom from all oppressive labels. These intersectional sites of oppression (e.g., racism and sexism) mean that criminalization labels and mental health labels operate in conjunction with one another. I now turn to explore the significance of mental health labeling in carceral spaces. 


\section{Mental Health Labels in Women's Carceral Spaces}

The research discussed above shows that women who are perceived to be challenging patriarchal authority are vulnerable to mental illness labels. The same holds true for incarcerated women. There is a large body of feminist work that focuses upon traditional notions of femininity in carceral spaces. In particular, Carol Smart's book, Women, Crime and Criminology (1977), problematizes the medicalization and pathologizing of women prisoners' behaviour by correctional staff. Building upon this work, considered the catalyst for contemporary feminist criminology, feminist scholarly work in criminology has grown exponentially (Chesney-Lind, 2006).

Studies of prison populations intensified during the 1980s as the relationship between 'gender as performance' and mental illness was applied to prison populations. One study that builds directly from such work is Baskin, Sommers, Tessler and Steadman's (1989) exploration of gender variation in the provision of mental health services in a New York State prison. The researchers took a random sample of approximately $10 \%$ of the total inmate population $(36,144), 142$ of whom were women (4\% of the sample) and 3,495 of whom were men (96\% of the sample). These percentages reflect the gender breakdown of the overall prison population at the time of the study. Their findings reveal that women are vastly overrepresented in mental health placements: $20 \%$ of women prisoners were in mental health placements versus only $8.7 \%$ of male prisoners.

Similar to Rosenfield's (1982) study of non-prisoners, Baskin et al. (1989) conclude that there is a correlation between gender incongruence and the provision of mental health services in prison. Women who display behaviours that were perceived as aggressive or violent were significantly more likely than men exhibiting the same behaviours to be labeled as pathological and placed in mental health units. As a corollary to this finding, incarcerated men who displayed behaviour typically labeled as 'feminine' (e.g., depression) were more likely to be placed in mental health units than women prisoners displaying the same symptoms (Baskin et al., 1989).

In a 1990 study, Chunn and Menzies maintain that even though incarcerated women are labeled mentally ill more frequently than incarcerated men, these women are not more likely than their male counterparts to be 'troubled' or 'maladjusted'. Rather, correctional agents are more likely to pathologize incarcerated women's behaviours through assumptive theories based upon perceived inherent sex differences and notions of femininity. According to Auerhahn and Leonard (2000), mental health units in women's prisons operate under a rubric of chivalry that conceptualizes women inmates as 'sick' and in need of 'treatment'. This 'treatment' rhetoric in the criminal justice system justifies the medicalization of women prisoners' 'problem' behaviours. Auerhahn and Leonard maintain that in mental health units, women are primarily prescribed psychotropic medications, such as antidepressants and antipsychotic agents. These medications are often used in carceral spaces for non-medical purposes, as "chemical restraints" (Auerhahn \& Leonard, 2000, p. 600 ) intended to transform non-feminine incarcerated women into docile bodies (Foucault, 1977). Stereotypical notions of femininity are enforced in carceral spaces; carceral agents value female docility because it is less threatening and easier to manage. Transgressors are labeled as pathological and drugged into submission. In addition, the stigmas associated with these labels serve to silence and discredit women who are resisting systems of patriarchal oppression.

Neve and Pate (2005) argue that at this contemporary, neoliberal moment, prisons are being restructured to serve as 'treatment centers'. They view cutbacks in public spending on mental health services in the community as having harshly affected young women with mental and cognitive disabilities in particular. Due to this clawback to government spending, women are becoming more easily trapped within the criminal justice system, as it becomes the default institution to 'help' those 
who display 'problem' behaviours. Neve and Pate reinforce this point by stating that "women are the fastest-growing prison population worldwide" (2005, p. 27). Furthermore, they argue that:

The increasing number of women in prison is clearly linked to the evisceration of health, education, and social services. The cycle of inadequate social services, criminalization, and incarceration intensifies in times of economic downturn. It is very clear where current policies are sending the people who are experiencing the brunt of the downturn in the economy. Jails are our most comprehensive homelessness initiative (Neve \& Pate, 2005, p. 27-28).

With more and more psychiatric and mental health facilities closing due to a lack of resources, individuals who are labeled as mentally ill ultimately become caught in the "stickier social control net of our criminal justice system" (Neve \& Pate, 2005, p. 28). Furthermore, once in prison, women tend to attract a number of psychiatric labels and be characterized as among the most difficult, highrisk prisoners to 'manage' (Neve \& Pate, 2005). According to Neve and Pate, "equating mental and cognitive disabilities with risks only serves to perpetuate a social construction of persons with mental disabilities as dangerous" (2005, p. 28). Consequently, many 'difficult' women in prison experience harsh penalties, including extended sentences, prolonged isolation, forced medicalization, physical restraints, and barriers to reintegration programming (Neve \& Pate, 2005).

\section{Method}

The aim of this research was to determine whether a newspaper's subjectivity - in particular its political affiliation and circulation audience - affects how Ashley Smith's story is told. To evaluate this objective, I purposefully selected newspapers from different political affiliations (liberal, conservative, and centrist) and circulation audiences (provincial or national). The four mainstream Canadian newspapers selected for analysis are: Globe and Mail (centrist), National Post (conservative), Toronto Star (liberal), and Telegraph-Journal (liberal). Two of these papers are nationally circulated (Globe and Mail, National Post), one is circulated in Ontario (Toronto Star), and one is based in New Brunswick (Telegraph-Journal).

In order to collect relevant news articles from these four newspapers, I used the online newspaper database ProQuest Newsstand. ProQuest Newsstand is the only accessible online database that archived articles from the Telegraph-Journal. I searched each newspaper individually, using the search parameters that I defined. Since I am not bilingual, the first parameter I set was for the database to only return results from 'English newspaper' sources. The second parameter set was the timeframe: articles that were written from October 18, 2007 until October 1, 2011. These dates were selected to ensure that the day of Ashley Smith's death (October 19, 2007) and the official cancellation date of the first inquest (September 30,2011) were included in the search. My final parameter defined which key terms ProQuest Newsstand was to search for in the four newspapers. In the keywords search bar, "Ashley Smith" (including quotation marks) was the only term searched. This was to ensure a return of all articles that mentioned Ashley Smith, which I then filtered for relevance by previewing each article. I deleted any news stories that did not directly discuss Ashley Smith. Within these parameters, my search yielded 235 Ashley Smith news stories: 37 from the Globe and Mail; 20 from the National Post; 103 from Telegraph-Journal; and 75 from the Toronto Star. 
For this research, the 235 newspaper articles that discussed the Ashley Smith case were critically read. According to Mahmood (n.d.), critical reading as a research method ${ }^{1}$ is:

An active approach to reading that involves an in depth examination of the text. Memorization and understanding of the text is achieved. Additionally, the text is broken down into its components and examined critically in order to achieve a meaningful understanding of the material (p. 2).

Zemliansky (2008) explains that critical reading involves questioning the face value of information. Researchers engaged in critical reading must "investigate, test, and even doubt every claim, every example, every story, and every conclusion" (Zemliansky, 2008, n.p.). However, engaging in critical reading does not mean that the reader must 'criticize' (or reject outright) the text. Instead, critical reading involves careful evaluations and analyses of a text's ideas and how they are constructed and presented (Zemliansky, 2008).

According to Mahmood (n.d.) and Zemliansky (2008) critical reading as a research method involves three key steps: previewing, writing, and critical reading. Previewing is when the researcher performs a brief screening of the text, scanning key words, headlines/titles, and references. This previewing stage allows the researcher to accomplish a general understanding of the text and form meaningful expectations from the reading (Mahmood, n.d.). The second step (writing) and third step (critical reading) occur simultaneously. Mahmood (n.d.) and Zemliansky (2008) argue that critical readers must take written notes while actively reading. Both authors suggest multiple note-taking strategies, including: underlining/highlighting key points, margin writing, divided page method, landmark/footnote method, journaling, and creating response questions. However, Mahmood (n.d.) and Zemliansky (2008) maintain that this writing step should only be done after the first reading of a text. Thus, critical reading involves multiple readings of the same text and written responses to the key arguments contained within these texts.

Following these three key steps as outlined by Mahmood (n.d.) and Zemliansky (2008), I first began my critical reading by previewing all 235 collected articles. In this previewing stage, I scanned over headlines, authors, and dates to verify their relevance to Ashley Smith and to gain an understanding as to what issues may be discussed. I then fully read each article through once and I highlighted any passages that I found salient. When I read each of these articles for a second time, I simultaneously created a reading journal in which I wrote down key arguments and my responses to those arguments. Emergent from this reading journal were three main themes: negative/generic terminology, vulnerability stereotypes, and alternative narratives. In the next section I outline in detail the implications of these themes.

\section{Discussion}

The main question guiding this research was whether stereotypical depictions of mental illness are reflected in the news articles about Ashley Smith from the four mainstream Canadian newspapers. The first theme emerging from my analysis is the reliance upon using generic references and

\footnotetext{
${ }^{1}$ Critical reading, as a method, is understood within this project as being situated in the wider methodological approach of critical discourse analysis (CDA). As such, I share the perspective that language (spoken and textual) and sociopolitical power structures share an intimate connection in either perpetrating or resisting the status quo (Fairclough, 1989).
} 
negative labels to describe Ashley as mentally ill. The analysis discloses that liberal and centrist newspapers used generic labeling in discussing Ashley's mental illness, where the conservative newspaper used negative terminology as a stand in for these generic terms. The second theme focuses on more mainstream liberal depictions of Ashley that minimize her 'prisoner' label through gendered mental illness stereotypes. These depictions bring portrayals of Ashley back to stereotypical mental illness labels through their emphasis of vulnerability, while they simultaneously move away from portraying her as a 'resistant' (and potentially dangerous) prisoner. The final theme that emerged from these news articles is the suggestion from some journalists that Ashley was not mentally ill. Instead, it is claimed that Ashley was an intentionally resistant prisoner, and as such, her 'negative behaviour' must be understood as something more complex than pathological symptomology. This possibility is only raised in liberal and centrist newspapers, and even in those papers it is only a suggestion. However, the fact that these 'alternative' stories of Ashley Smith exist signals that her experiences of imprisonment may be more complex than what was commonly portrayed.

\section{Generic References \& Negative Labels}

In the news coverage of Ashley Smith, journalists use many different terms to indicate to readers that she was mentally ill. Typically these mental illness labels are applied in the opening paragraph of the news article. A sample of some of the more frequently re-occurring mental health labels used include: "obviously troubled" (Brennan, 24 August 2010, A.9); "very troubled, desperately ill young Canadian" (Heard, 9 May 2011, A.12); "challenged young person" (McHardie, 21 November 2007, A.1); "mentally ill Moncton woman" (Linke, 21 November 2007, A.3); "an extremely troubled woman" (Linke, 20 May 2008, A.1); "a severely disturbed young woman" (Anonymous, 5 March 2009, A.6); "the emotionally disturbed 19-year-old" (Linke, 24 October 2008, A.1); "extremely challenging" (Linke, 24 October 2008, A.1); and "a mentally ill teen" (Pritchett, 9 June 2010, A.1). From this sample it is clear that in describing Ashley Smith journalists relied upon generic references (e.g., 'mentally ill') and negative terminology ('troubled', 'disturbed').

The specific terms 'disturbed' and 'troubled' are used to describe Ashley's mental illness at least once in all four newspapers. Although it may be tempting to view this trend as an attempt by journalists to be sympathetic, I argue in a later section that journalists tend to emphasize Ashley's vulnerability and helplessness to invoke audience pity. Instead of conjuring sympathy, the use of the words 'troubled' and 'disturbed' results in labeling Ashley Smith as someone who was out of control, potentially dangerous and 'out of touch' with reality. This indicates that these words reflect the negative stereotypes associated with mental illness. As argued by Wahl, Wood and Richards (2002), negative descriptors when used in conjunction with a mental illness label suggest that mentally ill individuals are "unchangeably dysfunctional and incapable of meaningful contributions to the community" (p. 25).

Wahl et al. (2002) also maintain that generic labels inaccurately present mental illness as a uniform condition which fails to acknowledge the "the varieties of disorders, symptoms and outcomes encompassed with the term mental illness" (p. 24). Even though most people diagnosed with a mental illness are neither violent nor dysfunctional, in generically describing Ashley Smith's 'problem' behaviours as a result of mental illness, readers are given the "impression that 'mental illness' is synonymous with severe disability" (Wahl et al., 2002, p. 24) and unpredictability. Only two (Toronto Star and Globe and Mail) of the four newspapers analyzed actually attempted to 
specify Ashley's mental illness. Each paper published one article in which the reporters used psychiatric assessments performed on Ashley when she was fifteen to show that she was mentally ill. Interestingly, each article described Ashley as having a different mental illness. For example, the Toronto Star preferred "oppositional defiant disorder" (Zlomislic, 10 October 2009, A.1) while the Globe and Mail described her as having a "learning disorder and borderline personality disorder" (Blatchford, 1 April 2011, A.10). This variation in diagnosis supports Caplan's (1995) claim that defining or classifying 'mental illness' is subjective and that mental health professionals rarely agree upon specific diagnoses and treatment plans. Each of the diagnoses applied to Ashley Smith represents a different set of symptoms and potential outcomes which range from mild to severe. In assigning specific diagnoses, mental health professionals are shaped by social, cultural, political, economic, ethnic, and gender factors (Doucet et al., 2010).

It is interesting that one of the diagnoses assigned to Ashley Smith is borderline personality disorder (BPD). According to Shaw and Proctor (2005):

The diagnosis of BPD is the latest manifestation of historical attempts to explain away the strategies which some women use to survive and resist oppression and abuse, by describing these strategies as symptomatic of a disturbed personality/pathology (p. 484).

The foundation of each of the two specific diagnoses applied to Ashley Smith rely upon stereotypical assumptions about gender expectations, predominately those influenced by white femininity - silence, passiveness and subordination (Shaw \& Proctor, 2005). Reflective of the arguments I have made in other sections, the gendered and racialized biases of mental illness labeling means that the diagnosis of BPD is most commonly applied to white women who deviate from feminine norms (Shaw \& Proctor, 2005). This is not to say that racialized women are immune from BPD diagnoses, but rather they are less likely to be understood as 'ill' and more likely to be labeled differently (e.g., aggressive, criminal) (De Genna \& Feske, 2013). According to Cauffman, Lexcen, Goldweber, Shulman and Grisson (2007), incarcerated girls are more likely than incarcerated boys to be diagnosed with disruptive behaviour disorders, such as oppositional defiant disorder or conduct disorder (p. 289). According to Pollack and Kendall (2005), BPD is one of the most dominant labels attached to imprisoned women, which is not all that surprising since carceral spaces are also misogynist and patriarchal spaces. Furthermore, they contend that in this context, BPD is a "pejorative" label "both because the behaviors [sic] exhibited by those given these diagnoses are often difficult for others to deal with and because BPD has traditionally been thought to be permanent and untreatable" $(2005$, p. 76$)$. Furthermore, in privileging a psycho-medical model that constructs women's 'difficult' behaviours as pathological, medical and penal systems continue to perpetuate "the invisibility of social and cultural influences" (Pollack \& Kendall, 2005, p. 76), such as histories of childhood abuse and previous victimization. Therefore, diagnosing women with BPD or 'oppositional personalities' allows for the maintenance of patriarchal oppression and control through the medicalization of women's 'difficult' (e.g., resistant) behaviours.

Although all four newspapers use these two negative terms, the National Post is the only newspaper that uses them as primary descriptors. In this newspaper, the terms 'troubled' and 'disturbed' are used in place of generic 'mentally ill' references. From the use of these terms that relate to mental and emotional states, the reader may infer that Ashley Smith was mentally ill. This result indicates that although negative terminology is present in each newspaper, the overall frequency in the use of these terms versus more generic vocabulary is minimal. However, the 
opposite is true for readers of the National Post since these negative terms are frequently used as the only descriptors of Ashley's mental illness. This means that the political affiliations of newspapers might affect how mental illness is depicted in news media. Though the conservative National Post does implicitly label Ashley Smith as mentally ill, this topic is not the primary focus of any of the articles published. In comparison, mental illness is the primary focus in approximately $12 \%$ of the Telegraph-Journal articles, $8 \%$ of the Toronto Star articles, and 3\% of the Globe and Mail articles. So although each newspaper labels Ashley Smith as mentally ill, the newsworthiness of this topic changes based on politics. This variation suggests that labeling Ashley Smith as mentally ill in news articles holds political significance.

\section{Ashley Smith was not a 'Hardened Criminal'}

According to the literature, stereotypes associated with mental illness labels vary depending on gender. Mentally ill men are typically associated with violence and dangerousness, whereas mentally ill women tend to be portrayed as vulnerable and dependent. As such, it is not surprising that Ashley Smith's vulnerability is emphasized, even though the picture presented of her was often not one of vulnerability. Some of the behaviours displayed by Ashley Smith (e.g., spitting, cursing, aggressiveness) are typically associated with masculinity and dangerousness. Even some of the charges against Ashley-most of which were laid in an institutional setting-are typically associated with violence and dangerousness: uttering threats, assault with a weapon, assaulting a peace officer, and possession of a prohibited weapon (Cheney, 21 November 2007, A.1). Despite these allegations, readers are prompted to conceptualize Ashley Smith through the rhetoric of vulnerability associated with her mental illness: "vulnerable, lonely, utterly miserable 19-year-old girl” (Blatchford, 20 May 2011, A.7); "[...] people like Ms. Smith, unseen, utterly powerless and vulnerable" (Anonymous, 18 May 2011, A.22). News articles about Ashley Smith minimize details that associate her with dangerousness and violence by focusing on the fact that she was a mentally ill white woman. Although this lop-sided depiction of a feminized Ashley Smith provides an ideal platform to invoke public sympathy, under this rubric of vulnerability Ashley Smith's behaviours are linked to pathology rather than intention and resistance.

Feminist researchers Chesler (1972) and Rosenfield (1982) maintain that when women transgress gender expectations, medical practitioners often explain away their behaviour as a symptom of 'illness'. Shaw and Proctor (2005) contend that when women are resistant to oppressive patriarchal authority, this resistance is pathologized as irrational and deviant. This pathologizing of gender role transgression is not limited to mental health professionals. Most liberal and centrist news articles written about Ashley Smith reduce her 'negative' behaviour to a sign that she was "an extremely troubled woman" (Linke, 20 May 2008, A.1). These depictions diminish the possibility of understanding Ashley's actions outside the stereotypical rubric of female pathology. In emphasizing Ashley Smith's vulnerability, mainstream news articles from the Toronto Star, Telegraph-Journal and Globe and Mail eliminate the possibility of discussion of the issue of punishing women who dissent from patriarchal authority.

The use of images of vulnerability, however, is not entirely negative. Liberal and centrist (Toronto Star, Telegraph-Journal, Globe and Mail) newspapers used Ashley's vulnerability as a platform to highlight Ashley's humanity and to challenge typical 'prisoner' labels. Given Ashley's aggressive behaviours and that she was incarcerated at the time of her death, it is expected that newspapers would use typical 'prisoner' labels. According to modified labeling theories, these 'prisoner' labels emphasize an individual's potential for dangerousness and would legitimatize 
punitive actions taken against him or her by prison officials. Counter to this expectation, liberal and centrist news articles that refer to Ashley as a 'prisoner' typically challenge the validity of applying this label to her. Acknowledging that Ashley was a person and a prisoner has the potential to direct attention to the processes and practices that create criminality, and to facilitate recognition of the political construction of crime and criminal behaviours. Additionally, humanizing Ashley also implicitly encourages readers to focus upon the actual prison practices (e.g., long-term segregation) that may have influenced her behaviour, and thus contributed to the construction of her as mentally ill.

Unfortunately, these liberal and centrist news articles on Ashley Smith dispute her 'prisoner' label by maintaining a dichotomous relationship between Ashley and 'other' prisoners. In this dichotomy, 'offender first' language is considered acceptable for incarcerated individuals who are not mentally ill. Offender first language emphasizes the 'offender' label over any other characteristic of the individual - the primary identity ascribed to the person is that of 'offender'. Similar to Becker's concept of 'master status' (1963), offender first language also affects how incarcerated individuals come to understand themselves as 'outsiders' (Becker, 1963). Prison reform advocates, such as Pollack (2007), maintain that 'offender first' language perpetuates the notion of a reified 'offender' identity and that individual criminality is the result of a rational choice of wrongdoing. This 'offender first' language legitimates biological deterministic theories, which argue that 'offenders' are biologically different from 'law-abiding people'. Frequently, liberal and centrist news articles draw on this distinction reminding readers that Ashley was not your 'typical hardened criminal'. As stated in an article that appeared in the Globe and Mail: "Ashley Smith was not a killer or a hardened criminal; she was a mentally ill 19-year-old with personality disorders" (Anonymous, 10 March 2009, A.16). With the exception of the National Post, this depiction of Ashley Smith is consistent across time and all newspapers:

What follows are just some of the measures to which [Ashley Smith] was subjected while in one form of custody or another in this country - and all of this, you must bear in mind, was done not to some hardened violent criminal, but to a mentally disturbed girl (Blatchford, Globe and Mail, 2 April 2011, A.2; emphasis added).

[Even though Ashley Smith's] behaviour was rooted in conditions over which she had little, if any, control, the justice system treated her as a delinquent (Anonymous, TelegraphJournal, 19 May 2011, A.8).

I was literally in tears. They were tears of sadness, anger and frustration over how this very troubled, desperately ill young Canadian was treated like a criminal when she needed care (Heard, Toronto Star, 9 May 2011, A.12).

This dichotomy is also accomplished by showcasing quotes from Ashley Smith's mother- "She was treated like a criminal, not a girl who needed help" (Thanh Ha, 3 March 2009, A.1) — and nonCorrectional Service of Canada professionals - "[Dr. Beaudry] said that she was treated as if she were a dangerous individual with little or no actual evidence that she was" (Makin, 3 November 2010, A.4). These portrayals of Ashley solidify a dichotomy between her and other 'prisoners', with the implication that the harsh punishments and penal practices Ashley experienced would be legitimate measures for prisoners who are not mentally ill. 
Different from the other three newspapers, the National Post challenges these depictions of Ashley Smith by maintaining her 'prisoner' label. While the other newspapers emphasize Ashley's 'mental health' label, the National Post focuses upon her 'prisoner' label. Consistently throughout the articles, readers of the National Post are reminded that Ashley was a prisoner:

Corrections Services of Canada yesterday fired four employees at the Grand Valley Institute for Women in Kitchener after an internal investigation into the death of inmate Ashley Smith (Anonymous, 17 January 2008, A.5).

The inmate died in hospital of what Waterloo Regional Police called self-initiated asphyxiation after being found unconscious in her cell at the Grand Valley Institution in Kitchener, Ont. last October (Huber, 24 October 2008, A.10).

Criminal charges have been withdrawn against four guards at the Grand Valley Institute for Women in Kitchener, in relation to the suffocation death of a 19-year-old female prisoner, the Crown attorney's office said yesterday (Crawford, 9 December 2008, A.9).

Smith, originally from Moncton, N.B., was the youngest prisoner at the institution [...] (Adam, 22 January 2010, A.5).

The articles provide no depictions that separate Ashley Smith's experience from that of 'other' prisoners. Unlike the other newspapers, news articles from the National Post typically label Ashley as a prisoner first, rather than as mentally ill. However, these news articles did discuss mental illness issues and implied that these details are relevant to Ashley's story because she was a woman prisoner. According to feminist literature, depicting all incarcerated women as mentally ill effectively pathologizes women's deviance and 'problem' behaviours. Women prisoners are presented as individuals who are 'sick' and in need of 'treatment'. Under this pathology discourse, resistant women prisoners are discredited and silenced. As such, these conservative depictions of Ashley Smith as a prisoner coincide with traditional assumptions of female prisoner pathology.

\section{Was She Sick, or Incorrigible While Incarcerated?}

In this final section on labeling Ashley Smith as mentally ill, I discuss an 'alternative' depiction of her story. In these stories, journalists question whether Ashley Smith should be labeled as mentally ill. These alternative perspectives only appear in the liberal and centrist newspapers (TelegraphJournal, Toronto Star, Globe and Mail), and appear infrequently. However, they are worthy of analysis because they indicate that Ashley's story may be more complicated than was typically depicted.

The Telegraph-Journal, a local New Brunswick newspaper, was the first newspaper to publish this different perspective, raising the question as to whether or not Ashley Smith was mentally ill before her imprisonment. For example, one journalist writes that Ashley Smith was a "happy and stable young girl before her imprisonment" (Southwick , 26 November 2007, A.1). In another Telegraph-Journal article, a quote from Bernard Richard challenges "any one of us to spend that kind of time - two or three years - in that kind of facility and I'd be willing to bet that we'd have our rough days as well" (McHardie, 21 November 2007, A.1). Journalist Rob Linke, from the Telegraph-Journal, writes: "Smith's mental health was tested many times but she was not 
found mentally ill" (24 October 2008, A.1). In the Globe and Mail, an article entitled "How Prison Only Made Her Worse" includes the observation:

On the streets of east-end Moncton, Ms. Smith had a reputation as a bit of a tough character. "She hung out with guys who caused trouble," a former schoolmate said. "She wasn't a girlie-girl, playing with Barbies." Her family saw a softer side, a girl who liked to read, paint and paddle a kayak (Cheney, 8 December 2007, A.1).

By writing that Ashley Smith was not officially labeled mentally ill prior to or while incarcerated, journalists from these newspapers problematize the assumption that Ashley's mistreatment was because she was mentally ill. These few stories disclose that Ashley was not provided with a psychological assessment during her time in federal custody. These articles indicate that while she was incarcerated, Ashley was labeled as 'difficult to manage' and a 'problem inmate'. Additionally, as shown by Cheney's quote, this narrative describes Ashley as someone who deviated from feminine ideals (e.g., not wanting to play with dolls as a young girl; considered a 'tough character'), which suggests that she may have also been resistant to the expectations of hegemonic femininity. In line with Baskin et al.'s (1989) study, women like Ashley who display traits typically associated masculinity are often read as 'risky' and responded to with punishment. Given Ashley's long-term placement in segregation cells, forced medicalization, and experiences of physical restraint, it is suggestive within these narratives that prison officials responded to her not as a mentally ill prisoner, but as a resistant prisoner.

Unfortunately, rather than pursuing this new angle of the mistreatment of a prisoner labeled 'difficult to manage', the journalists of each of these articles argued that not diagnosing Ashley as mentally ill was the problem. In doing so, they diminish the argument that Ashley's behaviours might have been intentionally resistant and/or coping behaviours in an intolerable situation. In doing so, they minimized the potential of these stories to offer a different side of Ashley's story. For example:

[Ashley Smith] was by all accounts a troubled young woman, but was jail the answer (Cheney, Globe and Mail, 8 December 2007, A.1)?

Smith was the emotionally disturbed 19-year-old inmate from Moncton whose death on Oct. 19, 2007 in the Grand Valley Institution for Women resulted in charges of criminal negligence causing death against three guards and a supervisor, as well as the firing of two prison managers (Linke, Telegraph-Journal, 24 October 2008, A.1).

Smith, who suffered from a mental illness, was not [given a choice] (Southwick, Telegraph-Journal, 26 November 2007, A.1).

To think [Ashley Smith, an] already challenged young person lived through this and ended up acting up "and then being charged and charged again, perhaps over 50 times, institutional charges" (McHardie, Telegraph-Journal, 21 November 2007, A.1).

There is one news article published in the Toronto Star that directly challenges labeling Ashley Smith as mentally ill. Rosie DiManno describes Ashley Smith as being "incorrigible while incarcerated" (9 March 2009, A.2) and maintains that it was because her resistant attitude "needed 
crushing" (March 2009, A.2) that she met punitive responses. DiManno depicted her as someone who was frequently combative and refused to passively accept prison authority. In this article, DiManno claims that Ashley was an "iconoclast" (9 March 2009, A.2) and challenged the notion that her behaviour was the result of a mental illness:

In page after page of analysis, [Ashley Smith] is described as defiant, combative, unyielding to rules, refusing to conform: an obstinate and powerful personality, the proverbial square peg being forced to fit into a round hole, a juvenile iconoclast who fought tooth and nail in hanging on to a personality others deemed "oppositional" and "narcissistic" and "disrespectful".

But the more she resisted, the further she was restricted and punished, caught in a crazy Catch-22 that had disaster written all over it.

However disturbed, rebellious, as an adolescent, Ashley Smith was sane. It was the adults — screws and jailers and clipboard clods — who made her crazy (DiManno, 9 March 2009, A.2).

This narrative presents Ashley Smith as a woman who was defiant, aggressive, and vocal. Unlike the journalists before, DiManno does not deflect this image of Ashley with mental illness labels. This alternative depiction of Ashley as resistant supports the analysis that labeling her 'disturbed' is subjective and rooted in medicalization and patriarchal understandings.

Although this 'alternative' story is only published once and only appears in the Toronto Star, the fact that it exists signals that Ashley's story may be more complex than was presented in the other news articles. This alternative story that introduced Ashley as intentionally resistant prods readers to consider the repercussions of resistance for women in carceral spaces.

\section{Conclusion}

Gendered mental illness stereotypes discussed by modified labeling theorists were reflected in the news coverage on Ashley Smith. However, the stereotypes used varied depending on the political affiliation of the newspaper. Liberal and centrist newspapers (Toronto Star, Telegraph-Journal, Globe and Mail) tended to align with stereotypes that portrayed mentally ill women as vulnerable. On the other hand, the conservative newspaper (National Post) presented a less sympathetic portrayal of Ashley by using negative mental illness terminology and emphasizing her 'prisoner' label. As this analysis illustrates, mental illness labeling in the media is often more complex than has been previously discussed in the extant literature. This research contributes to modified labeling theories by lending support to their main theoretical assertion that mental illness labels are socially constructed and affected by many sociopolitical factors, while considering the influence of news coverage timing and newspaper political affiliation on the depictions of mental illness stereotypes in mainstream news media.

\section{Acknowledgements}

I would like to thank Dr. Diana Majury, Dr. Debra Graham, Dr. Diana Young, as well as the blind reviewers and editors of CGJSC for their contributions. 


\section{About the Author}

Jessi Ring is completing her MA in Women and Gender Studies at Carleton University, and is beginning a $\mathrm{PhD}$ in Legal Studies. Her research interests include feminist criminology, penal and law reform, feminist activism and new media. She can be reached at Jessica.Ring@ carleton.ca

\section{References}

Adam, B.A. (22 January 2010). Ex-supervisor found not guilty of assaulting teen prisoner; Ashley Smith Case. National Post; Sect. A.5.

Anonymous. (17 January 2008). Employees fired over woman's death. National Post; Sect. A.5.

--. (5 March 2009). Killed by indifference. Telegraph-Journal; Sect. A.6.

--. (10 March 2009). Shocking report a wake-up call. Toronto Star; Sect. A.16.

--. (18 May 2011). The need to know. Globe and Mail; Sect. A.22.

--. (19 May 2011). Save the next Ashley Smith. Telegraph-Journal; Sect. A.8.

Auerhahn, K. \& Dermody Leonard, E. (2000). Docile Bodies? Criminal Restraints and the Female Inmate. Journal of Criminal Law and Criminology, 90(2), 599-634.

Baskin, D.R., Sommers, I., Tessler, R., \& Steadman, H.J. (1989). Role Incongruence and Gender Variation in the Provision of Prison Mental Health Services. The Journal of Health and Social Behaviour, 30(3), 305-314.

Blatchford, C. (1 April 2011). Ashley Smith's family challenges coroner's decision to ignore videos. Globe and Mail; Sect. A.10.

--. (20 May 2011). If hospitals worked like this, we'd all be in serious danger. Globe and Mail; Sect. A.7.

--. (21 June 2011). Inquest going nowhere fast; Delays compound Ashley Smith tragedy. National Post; Sect. A.1.

Blum, A. (2011). The Grey Zone of Health and Illness: Bristol: Intellect Ltd.

Brennan, R.J. (24 August 2010). Feds to release documents on teen who took life in jail. Toronto Star; Sect. A.8. 
Caplan, P.J. (1995). They Say You're Crazy: How the World's Most Powerful Psychiatrists Decide Who's Normal. Reading, MA: Addison-Wesley Publishing Company

Cauffman, E., Lexcen, F.J., Goldweber, A., Shulman, E.P., \& Grisso, T. (2007). Gender Differences in Mental Health Symptoms Among Delinquent and Community Youth. Youth Violence and Juvenile Justice, 5(3), 287-307.

Cheney, P. (21 November 2007). Teen's death sparks prison furor. Globe and Mail; Sect. A.1.

--. (8 December 2007). How prison 'only made her worse'. Globe and Mail; Sect. A.1.

Chesler, P. (1972). Women and Madness. New York: Avon Books.

Chesney-Lind, M. (2006). Patriarchy, Crime, and Justice: Feminist Criminology in an Era of Backlash. Feminist Criminology, 1(1), 6-26.

Chunn, D.E., \& Menzies, R.J. (1990). Gender, Madness and Crime: The Reproduction of Patriarchal and Class Relations in a Psychiatric Court Clinic. The Journal of Human Justice 1.2: 33-54.

Correctional Service of Canada. (2012). Institutional Profiles: Grand Valley Institution for Women. Ottawa: Correctional Service of Canada.

Crawford, T. (9 December 2008). Charges withdrawn against guards in suffocation death of teen prisoner; Ashley Smith, 19.

Davis, A. (2007). Race and Criminalization: Black Americans and the Punishment Industry. In J.F. Healey and E. O'Brien (Eds.), Race, Ethnicity, and Gender Selected Readings. (pp. 204-222). London: SAGE Publications Ltd.

De Genna, N.M. \& Feske, U. (2013). Phenomenology of borderline personality disorder: the role of race and socioeconomic status. The Journal of Nervous and Mental Disease, 201(12), 1027-1034.

DiManno, R. (9 March 2009). Square peg beaten down by system. Toronto Star; Sect. A.2.

Doucet, S., Letourneau, N., \& Stoppard, J. (2010). Contemporary paradigms of research related to women's mental health. Health Care for Women International, 31(4), 296312 .

Fairclough, N. (1989). Language and Power. London: Longman. 
Foucault, M. (1977). Discipline and Punish: The Birth of the Prison. New York: Pantheon Books.

Friedan, B. (1963). The Feminine Mystique. New York: W.W. Norton \& Company, Inc.

Gary, F.A. (2005). Stigma: Barrier to Mental Health Care Among Ethnic Minorities. Issues in Mental Health Nursing, 26, 979-999.

Huber, J. (24 October 2008). Guards 'not to enter' teen's cell even if face turns purple; Ashley Smith Report; Officers scapegoats in her self-asphyxiation case, union charges. National Post; Sect. A.10.

Jiwani, Y. (2002). The Criminalization of "Race", the Racialization of Crime. In W. Chan and K. Mirchandani (Eds.), Crimes of Colour: Racialization and the Criminal Justice System of Canada (pp. 67-101). Toronto: Broadview Press, Ltd.

Link, B.G. \& Cullen, F.T. (1986). Contact with the Mentally Ill and Perceptions of How Dangerous They Are. Journal of Health and Social Behavior, 27, 289 - 303.

Linke, R. (21 November 2007). Teen alleged she was assaulted by jail staff; Revelations New details emerge in Ashley Smith's death. Telegraph-Journal; Sect. A.3.

--. (20 May 2008). National pattern of prison deaths: report; Spotlight How badly prison service responds to suicidal and life-threatening situations. Telegraph-Journal; Sect. A.1.

--. (24 October 2008). Her final moments; Defence Union backs guards in report on death of troubled teen Ashley Smith. Telegraph-Journal; Sect. A.1.

Mahmood, K. (n.d.). Critical Reading [PowerPoint slides]. Online: www.paklag.org/4Critical\%20Reading-Khalid.ppt.

Makin, K. (3 November 2010). Probe set to expand beyond teen's death. Globe and Mail; Sect. A.16.

McHardie, D. (21 November 2007). Watchdog proposes new youth centre; Idea Close youth jail create new incarceration and mental health facility. Telegraph-Journal; Sect. A.1.

McLeod, S. (2008). The Medical Model. SimplyPsychology. Online: http://www.simplypsychology.org/medical-model.html. 
Morgan, C., McKenzie, K., \& Fearon, P. (Eds.). (2008). Society and Psychosis. Cambridge: Cambridge University Press.

Neve, L. \& Pate, K. (2005). Chapter 2: Challenging the Criminalization of Women Who Resist. In J. Sudbury (ed.), Global Lockdown: Race, Gender, and the Prison-Industrial Complex (pp. 19-35). New York: Routledge.

O'Connor, T. (2006). Labeling Theories of Crime. MegaLinks in Criminal Justice. Online: http://www.drtomoconnor.com/1060/1060lect07.htm.

Pasman, J. (2011). The Consequences of Labeling Mental Illness on the Self-Concept: A Review of the Literature and Future Directions. Social Cosmos, 2, pp. 122-127.

Pollack, S. (2007) "I'm Just Not Good in Relationships": Victimization Discourses and the Gendered Regulation of Criminalized Women. Feminist Criminology, 2(2), 158174.

Pollack, S. \& Kendall, K. (2005). Taming the shrew: Regulating prisoners through women-centered mental health programming. Critical Criminology, 13(1), 71-87.

Poussaint, A.F. (1990). Mental Health Status of Black Americans, 1983. In D.S. Ruiz (Ed.), Handbook of Mental Health and Mental Disorder Among Black Americans (pp. 17-55). USA: Greenwood Press.

Pritchett, J. (9 June 2010). Child advocate opposes proposed changes; Justice: Bernard Richard to appear before Commons committee to express his concerns to MPs. Telegraph-Journal; Sect. A.1.

Richard, B. (2008). The Ashley Smith Report. Fredericton: Office of the Ombudsman and Child and Youth Advocate.

Rogers, A. \& Pilgrim, D. (2010). A Sociology of Mental Health and Illness. Fourth Edition. Berkshire: Open University Press.

Rosenfield, S. (1982). Sex Roles and Societal Reactions to Mental Illness: The Labeling of "Deviant" Deviance. Journal of Health and Social Behavior, 23(1), 18-24.

--. (2012). Triple Jeopardy? Mental health and the intersection of gender, race, and class. Social Science \& Medicine, 74(11), 1791-1801.

Sapers, H. (2008). A Preventable Death. Ottawa: Office of the Correctional Investigator. 
Scheff, T.J. (1974). The Labeling Theory of Mental Illness. American Sociological Review 39, no. 3, 444-452.

--. (1999). Being Mentally Ill: A Sociological Theory. New York: Aldine De Gruyter.

Shaw, C. \& Proctor, G. (2005). Women at the Margins: A Critique of the Diagnosis of Borderline Personality Disorder, 15(4), 483- 490.

Sieff, E. (2003). Media frames of mental illnesses: The potential impact of negative frames. Journal of Mental Health, 12(3), 259-269.

Silliman, J. \& Bhattacharjee, A. (2002). Policing the National Body: Race, Gender, and Criminalization. Cambridge: South End Press.

Southwick, R. (26 November 2007). Woman calls herself 'Grand Valley success story'; Prison Former inmate shows alternative view of federal women's center where Moncton teen died. Telegraph-Journal; Sect. A.1.

Thanh Ha, T. (3 March 2009). Instructed to curtail crushing red tape, guards watched girl die in her cell. Globe and Mail; Sect. A.1.

Wahl, O.F. (1995). Media madness: Public images of mental illness. New Brunswick: NJ: Rutgers University Press.

Wahl, O.F., Wood, A., and Richards, R. (2002). Newspaper Coverage of Mental Illness: Is It Changing? Psychiatric Rehabilitation Skills, 6(1), 9-31.

Zimliansky, P. (2008). Chapter 3: Research and Critical Reading. Methods of Discovery: A Guide to Research Writing. Online: http://methodsofdiscovery.net/?q=node/8.

Zlomislic, D. (10 October 2009). How this generous girl became a 'caged animal'. Toronto Star; Sect. A.1. 